\title{
Close and Distant. Political Executive-Media Relations in Four Countries
}

\author{
Karl Magnus Johansson \& Gunnar Nygren (red.) \\ Göteborg: Nordicom 2019 \\ 264 sider. ISBN 9789188855060
}

\begin{abstract}
Anmeldt av Elin Strand Larsen [førsteamanuensis, Høgskolen i Østfold, elin.strand.larsen@hiof.no]
\end{abstract}

Denne antologien, redigert av Karl Magnus Johansson og Gunnar Nygren, er basert på et treårig forskningsprosjekt om forholdet mellom journalister og politiske kilder i fire forskjellige land - Finland, Litauen, Polen og Sverige - i perioden 2014-2017. Prosjektet er basert på dokumentanalyse og 20-25 intervjuer med politikere, pressesekretærer og journalister i hvert av de fire landene. Forskningsarbeidet fremstår grundig og godt koordinert.

Antologien består av tre deler og elleve kapitler. Den første delen inkluderer fire landsspesifikke kapitler. Basert på 21 intervjuer i Finland finner Risto Niemikari, Tapio Raunio og Tom Moring at forholdet mellom politiske kilder og journalister preges av gjensidig avhengighet. Det er lett å få tilgang til politiske kilder, og til tross for snakk om økende profesjonalisering og avstand preges forholdet fortsatt av uformell og personlig kontakt. Samtidig viser studien fra Finland at regjeringens kommunikasjon utad har blitt mer sentralisert, og at journalistene prioriterer de mest sentrale politiske kildene, som statsminister, finansminister og utenriksminister.

I Litauen viser analysen til Auksė Balčytienė og Milda Malling at det er et nært forhold mellom journalister og politiske kilder, noe som kan spores tilbake til landets uavhengighet og selvstendiggjøring på 1990-tallet. Den formelle kontakten preges av profesjonalitet, men i skyggen av dette ser vi fortsatt i dag uformelle sosiale nettverk med egne maktrelasjoner og hierarkiske strukturer. Studien viser at den kulturelle arven i Litauen fortsetter å ha betydning, til tross for store politiske, økonomiske og teknologiske endringer. Globale trender innen journalistikk og politisk kommunikasjon setter sitt preg, men må samtidig forstås i sammenheng med den lokale konteksten i Litauen.

I kapitlet om Polen argumenterer Bogusława Dobek-Ostrowska og Jacek Nożewski for at parlamentsvalget i 2015, hvor Partiet for lov og rettferdighet kom til 
makten, endret både den politiske kommunikasjonen og journalisters tilgang til politiske kilder. Spesielt når den politiske situasjonen er spent, opplever journalistene at politikerne blir mindre tilgjengelige, og at pressesekretærene blokkerer informasjonsflyten. Et annet viktig funn gjelder bruken av sosiale medier i Polen, som både politikere og media benytter for å bygge egen merkevare.

Karl Magnus Johansson, Milda Malling og Gunnar Nygren beskriver forholdet mellom journalister og politiske kilder i Sverige som en profesjonell symbiose. Samtidig påpeker de at politikerne ser ut til å ha overtaket i sin samhandling med journalister. En årsak til dette kan være nedbemanningen i svenske nyhetsredaksjoner, samtidig som den politiske kommunikasjonen blir stadig mer profesjonell. Forholdet mellom journalister og politiske kilder er basert på en medielogikk, men det betyr ikke at mediene får bestemme. Ved å kontrollere informasjonen de sender ut til utvalgte redaksjoner, kan de politiske kildene i stor grad påvirke medienes dagsorden, samtidig som journalistene har mer å si når det kommer til hvordan nyhetene rammes inn og presenteres.

Den andre delen av antologien består av fem kapitler som tar for seg ulike temaer som analyseres på tvers av de fire landene. I det første komparative kapitlet tar Karl Magnus Johansson og Tapio Raunio for seg politisk kommunikasjon basert på to casestudier fra henholdsvis Finland og Sverige samt to eksempler fra henholdsvis Litauen og Polen. Ser vi en trend der stadig mer av regjeringens kommunikasjon utad er sentralt koordinert og kontrollert? De to casestudiene fra Finland og Sverige støtter en slik sentraliseringshypotese. Kommunikasjonen håndteres sentralt, gjerne ved statsministerens kontor, for å fremstå mer koordinert og enhetlig - som at regjeringen snakker med én stemme. Johansson og Raunio finner imidlertid ikke den samme tydelige kommunikasjonskoordineringen i Litauen og Polen, noe som tyder på at sentraliseringshypotesen har noen begrensninger.

I det andre komparative kapitlet studerer Elena Johansson politisk kommunikasjon i sosiale medier - Facebook og Twitter - i Finland, Polen og Sverige. En styrke ved denne studien er at Johansson også, i tillegg til intervjuer, har samlet kvantitative data om hvordan statsråder og deres pressesekretærer benytter disse sosiale mediene. Analysen viser at kommunikasjonsstrategiene er forskjellige på Facebook og Twitter, men tilnærmet de samme på tvers av de tre landene. Facebook brukes primært for å bygge egen merkevare, mens dialogen med velgerne er begrenset. Twitter benyttes oftere for å gå i dialog om bestemte temaer, men dialogen foregår som oftest mellom eliter i politikken og media.

Kapitlet til Milda Malling tar utgangspunkt i Herbert Gans' beskrivelse av forholdet mellom kilder og journalister som en dans. Selv om det må to til for å danse, kan enten kildene eller journalistene føre. Basert på intervjuer med journalister og politiske kilder i Litauen og Sverige viser Malling at forholdet er mer nyansert enn «informasjon i bytte mot publisitet». Spesielt uformell kontakt mellom kilder og journalister er basert på gjensidig tillit, forventninger som møtes og vennskapelige bånd bygd opp over tid. Gunnar Nygren og Risto Niemikari setter spørsmålstegn ved om 


\section{6 | ELIN STRAND LARSEN}

medielogikken overkjører den politiske logikken i samhandlingen mellom journalister og politiske kilder. Det er ikke slik at den ene logikken utelukker den andre. Gjennom en analyse av forholdet mellom journalister og politiske kilder på mikro-, meso- og makronivå viser Nygren og Niemikari at det ikke bare skjer en medialisering av politikken, men også at politikere benytter medielogikken til å oppnå politiske mål.

I femte og siste komparative kapittel sammenligner Auksė Balčytienè og Tom Moring politisk kommunikasjonskultur i Finland, Litauen, Polen og Sverige. De henter inspirasjon fra Hallins og Mancinis klassiske klassifisering av fire ulike mediesystemer (den polarisert-pluralisme-modellen, den demokratisk-korporative modellen, den liberale modellen og den postkommunistiske modellen), men fremholder også at denne typologien ikke får frem alle nyansene som er til stede i de fire landene. Ved å benytte en matrise over politisk system og medienes rolle viser Balčytienė og Morning at både Sverige og Finland har et pluralistisk politisk system, og at mediene spiller en aktiv rolle i formidlingen av politikk. I Sverige er imidlertid journalistene mer kritiske enn i Finland, hvor de fremstår mer kollegiale. Litauen og Polen skiller seg fra de to nordiske landene ved å ha et mer restriktivt politisk system. Samtidig fremstår mediene i Polen som mer passive i sin formidling av politikk, til forskjell fra Litauen, hvor journalistikken er mer kritisk i tråd med medieeiernes interesser.

I tredje del av antologien finner vi en oppsummering fra Karl Magnus Johansson og Gunnar Nygren. Det treårige forskningsprosjektet viser at forholdet mellom journalister og politiske kilder er preget av både nærhet og avstand - gjensidig nytte og motstridende interesser. Den komparative studien er et svært viktig bidrag til å forstå forholdet mellom journalister og politiske kilder i Finland, Litauen, Polen og Sverige. Mitt forslag er at en eventuell oppfølgingsstudie bør inkludere empiriske feltstudier som viser hvordan journalister og politiske kilder rent faktisk samhandler, ikke bare hvordan de beskriver sitt forhold. Det hadde også vært interessant å se i hvilken grad kjønn spiller inn på forholdet mellom journalister og politiske kilder i de fire landene. 